\title{
Kajian Daya Tampung dan Mutu Kelas Air Daerah Aliran Sungai Banjir Kanal Timur, Kota Semarang
}

\author{
Thomas Triadi Putranto ${ }^{1}$
}

Departemen Teknik Geologi, Universitas Diponegoro, Semarang, Indonesia

\author{
Novie Susanto \\ Departemen Teknik Industri, Universitas Diponegoro, Semarang, Indonesia
}

Artikel Masuk : 8 Mei 2018

Artikel Diterima : 26 Juli 2019

Tersedia Online : 31 Agustus 2019

\begin{abstract}
Abstrak: Pertambahan penduduk setiap tahun yang meningkat dan perkembangan ekonomi yang pesat di Kota Semarang menyebabkan permasalahan lingkungan terkait penggunaan sumber daya air. Salah satu dampak permasalahan lingkungan yaitu kerusakan Daerah Aliran Sungai (DAS) Banjir Kanal Timur (BKT). Penelitian ini bertujuan untuk mengidentifikasi potensi dan kondisi DAS BKT, serta segmentasi sungai sebagai dasar penetapan titik pantau yang representatif yang digunakan untuk mengetahui daya tampung yang sesuai dengan gambaran kelas air per segmentasi sungai. Metode penelitian yang digunakan dalam penelitian ini adalah pendekatan analisis deskriptif dan kuantitatif dari hasil pengamatan dan pengukuran kondisi air DAS Sungai BKT di lapangan serta analisis laboratorium. Selain itu penelitian ini juga menggunakan pemodelan QUAL2E untuk menentukan estimasi beban cemaran dan daya tampung cemaran sungai BKT. Hasil analisis kualitas menunjukkan Sungai BKT memiliki kualitas air melebihi ambang batas bila ditinjau dari parameter DO, BOD, dan fecal coliform, sedangkan untuk parameter $\mathrm{NO}_{3}$ dan $\mathrm{NO}_{2}$ air Sungai BKT di bawah ambang batas. Segmen yang memiliki daya tampung beban cemaran BOD adalah segmen 1. Untuk segmen yang memiliki daya tampung beban cemaran Nitrit $\left(\mathrm{NO}_{2}\right)$ dan Nitrat $\left(\mathrm{NO}_{3}\right)$ adalah segmen 1 hingga segmen 4. Segmen yang memiliki daya tampung beban cemaran fecal coliform adalah segmen 2. Dari hasil penelitian, dapat disimpulkan bahwa Segmen 1 dapat dimasukkan ke dalam sungai kelas II, sedangkan segmen 2 masuk ke dalam sungai kelas III. Segmen 3 dan 4 masuk ke dalam sungai kelas IV.
\end{abstract}

Kata Kunci: beban pencemaran; daya tampung beban cemaran; QUAL2E; Sungai Banjir Kanal Timur

Abstract: The increasing population every year and the rapid economic development in Semarang City caused environmental problems related to the water resources used. One of the impacts of environmental problems is the lowering water quality of the Banjir Kanal Timur (BKT) Watershed. The study aims to identify the potential and conditions of the BKT watershed, and river segmentation as a basis for determining representative monitoring points that are used to determine the capacity that is adjusted to the description of river water segmentation class. The methods were descriptive and quantitative analysis approach based on the observation and measurement in the field campaign as well as the laboratory analysis. In addition, this research was also compiling the QUAL2E modeling to determine estimation

\footnotetext{
${ }^{1}$ Korespondensi Penulis: Departemen Teknik Geologi, Universitas Diponegoro, Semarang, Indonesia email: putranto@ft.undip.ac.id
} 
of contamination load and capacity of contamination of Banjir Kanal Timur. The results conducted that the BKT has poor water quality based on the parameters of DO, BOD, and fecal coliform, while for the $\mathrm{NO}_{3}$ and $\mathrm{NO}_{2}$ parameters indicate good water quality. Segment that has load capacity of $B O D$ contamination is segment 1. Segments that have load capacity of Nitrite $\left(\mathrm{NO}_{2}\right)$ and Nitrate $\left(\mathrm{NO}_{3}\right)$ contents are segment 1 to segment 4 . The segment which has load capacity of contamination of fecal coliform is segment 2. Thus, Segment 1 can be classified into second class while segment 2 goes into third class. Furthermore, segment 3 and 4 are into fourth class respectively.

Keywords: Banjir Kanal Timur River; carrying capacity of contaminant load; contaminan load; QUAL2E

\section{Pendahuluan}

Kerusakan ekosistem Daerah Aliran Sungai (DAS) menyebabkan terjadinya erosi, sedimentasi, berkurangnya sumber mata air bahkan penurunan kualitas air di bagian hilir. Pada DAS Banjir Kanal Timur (BKT), kerusakan lingkungan di DAS dipercepat oleh pertambahan penduduk yang setiap tahun meningkat dan perkembangan perekonomian di Kota Semarang juga menyebabkan tekanan terhadap sumber daya alam semakin meningkat (Pavita, Widiatmono, \& Dewi, 2014). Permasalahan pemanfaatan lahan dan air pada akhirnya akan berpengaruh terhadap daya tampung dan mutu kelas air sungai untuk mendukung perikehidupan manusia dan makhluk hidup lain (Suparjo, 2009). Oleh karena itu, perlu adanya upaya pengendalian pencemaran air sungai agar kualitas air sungai tetap berfungsi sesuai peruntukkannya (Hakki, Sugiyanta, \& Haryono, 2015). Upaya pemantauan kualitas air hendaknya diarahkan pada satu pola kebijakan pengelolaan DAS yang komprehensif, sehingga kegiatan manusia baik di bidang industri, permukiman, pertanian, dan lain-lain yang biasanya menimbulkan masalah dalam lingkungan DAS seperti pencemaran air, menurunnya kualitas sumber daya alam, lahan kritis, gangguan kesehatan, penurunan potensi sumber daya hayati, bencana tanah longsor, banjir serta sedimentasi di bagian hilir sungai.

Penelitian ini bertujuan untuk mengidentifikasi potensi dan kondisi DAS BKT, serta segmentasi sungai sebagai dasar penetapan titik pantau yang representatif yang digunakan untuk mengetahui daya tampung yang disesuaikan dengan gambaran kelas air per segmentasi sungai. Pemodelan numerik menggunakan QUAL2E juga digunakan untuk menentukan secara kuantitatif estimasi beban cemaran dan daya tampung cemaran di DAS BKT seperti yang dilakukan oleh peneliti-peneliti di beberapa sungai lain (Barnwell, Jr, Brown, \& Whittemore, 2004; Jaworska, Masscheleyn, \& Mcavoy, 2001; Parveen \& Singh, 2016). Sementara penelitian kuantitatif serta kualitatif lain terkait kualitas air, status mutu air sungai dan potensi pemanfaatannya juga dilakukan beberapa peneliti lain (Anhwange, Agbaji, \& Gimba, 2012; Blume et al., 2010; Brahmana \& R, 2008; Kurniawan, 2017; Priyambada, Oktiawan, \& Suprapto, 2008; Rahayu \& Tontowi, 2009; Salmin, 2005; Sholichin, Othman, \& Limantara, 2010; Siahaan, Indrawan, Soedharma, \& Prasetyo, 2011; Sofia, Tantowi, \& Rahayu, 2010; Sutriati, 2011; Syofyan, Usman, \& Nasution, 2011; Vagnetti, Miana, Fabris, \& Pavoni, 2003; Winata, Siswoyo, \& Mulyono, 2000; Yudo, 2010). Penelitian yang pernah dilakukan di Sungai BKT didominasi oleh analisis hidrologi terkait perencanaan sistem drainase (Asrori \& Saputro, 2017), pengembangan Sungai BKT untuk tujuan wisata (Ma'rruf, Graha, Salamun, \& Ismiyati, 2015), serta analisis lingkungan pemanfaatan bantaran Sungai BKT (Anggani, 2005). Dengan demikian penelitian terkait daya tampung dan mutu kelas air Sungai BKT belum pernah dilakukan sebelumnya.

Secara geografis menggunakan sistem koordinat Universal Transverse Mercator (UTM) DAS BKT terletak di antara 9219884 - $9233053 \mathrm{mU}$ dan 435478 - $443241 \mathrm{mT}$. DAS BKT terletak pada ketinggian antara 0 meter di atas permukaan laut (mdpl) di bagian utara 
(hilir) hingga 272 mdpl, meliputi empat puluh tiga kelurahan yang terletak di beberapa wilayah kecamatan, yaitu: Kecamatan Tembalang, Banyumanik, Candisari, Gayamsari, Semarang Selatan, Semarang Timur, Gajah Mungkur, Pedurungan, Semarang Utara, dan Genuk (BPS Kota Semarang, 2016).

\section{Metode Penelitian}

Metode penelitian yang digunakan dalam penelitian ini adalah pendekatan analisis deskriptif dan kuantitatif dari hasil pengamatan dan pengukuran kondisi di lapangan serta analisis laboratorium, sebagaimana yang dijelaskan pada Gambar 1. Pengambilan sampel dilakukan dengan cara pengukuran langsung di sepanjang DAS BKT dari hulu sampai dengan hilir. Pengambilan sampel dilakukan selama satu hari pada setiap titik sampling berdasarkan segmentasi sungai yang telah ditentukan (BSN, 2008). Setelah data yang terkumpul diolah, maka selanjutnya akan dilakukan analisis kualitas air sungai dengan cara membandingkan hasil analisis parameter yang diteliti yaitu dissolved oxygen (DO), biological oxygen demand (BOD), nitrat $\left(\mathrm{NO}_{3}\right)$, nitrit $\left(\mathrm{NO}_{2}\right)$, dan fecal coliform dengan Peraturan Pemerintah (PP) Nomor 82 Tahun 2001 tentang Pengelolaan Kualitas Air dan Pengendalian Pencemaran Air (Pemerintah Republik Indonesia, 2001). Setelah itu dilakukan analisis lanjutan untuk menentukan kualitas air berdasarkan kelas air. Selanjutnya perhitungan beban pencemar yang masuk ke dalam Sungai BKT dapat dilakukan dengan metode estimasi dan perhitungan daya tampung beban pencemaran terhadap parameter $\mathrm{DO}, \mathrm{BOD}, \mathrm{NO}_{3}, \mathrm{NO}_{2}$, dan fecal coliform dengan pemodelan QUAL2E. Setelah didapatkan hasil pemodelan QUAL2E, kemudian dilakukan penghitungan beban cemaran terukur dan kemudian dibandingkan dengan beban cemaran yang diizinkan sesuai baku mutu pada Peraturan Pemerintah Nomor 82 tahun 2001 tentang Pengelolaan Kualitas Air dan Pengendalian Pencemaran Air. Dengan demikian akan diketahui besarnya daya tampung beban cemaran untuk parameter $\mathrm{DO}, \mathrm{BOD}, \mathrm{NO}_{3}, \mathrm{NO}_{2}$, dan fecal coliform sesuai dengan Keputusan Menteri Lingkungan Hidup (KepMenLH) No 115 Tahun 2003 dan KepMenLH No 110 Tahun 2003 (Keputusan Menteri Lingkungan Hidup Republik Indonesia, 2003b, 2003a). Tabel 1 dan Gambar 2 merupakan lokasi pengambilan sampel air di DAS BKT. Penelitian dilakukan dengan mengambil lima sampel pada yang tersebar pada empat segmen. Titik 1 terletak di Pucang Gading Dolog Penggaron mewakili wilayah hulu DAS BKT. Titik 2 terletak di Jomblang, Kecamatan Candisari dan Titik 3 terletak di Pandean Lamper, Kecamatan Gayamsari mewakili bagian tengah DAS BKT dan wilayah padat penduduk. Titik 4 terletak di Sambirejo, Kecamatan Gayamsari untuk mewakili keberadaan peternakan. Titik 5 terletak di Kemijen, Kecamatan Semarang Utara sebagai daerah hilir DAS BKT.

Tabel 1. Lokasi Pengambilan Sampel DAS Sungai BKT

\begin{tabular}{lcccl}
\hline & & \multicolumn{2}{c}{ Koordinat } & \\
\cline { 3 - 4 } No & Titik & X & Y & \\
& & & & Desa/Kecamatan \\
\hline 1 & Titik Sampel 1 & 442988 & 9221742 & Pucang Gading Dolog Penggaron, Kec. Pedurungan \\
2 & Titik Sampel 2 & 438317 & 9224728 & Jomblang, Kec. Candisari \\
3 & Titik Sampel 3 & 438080 & 9226545 & Pandean Lamper, Kec. Gayamsari \\
4 & Titik Sampel 4 & 438331 & 9227930 & Sambirejo, Kec. Gayamsari \\
5 & Titik Sampel 5 & 438205 & 9231127 & Kemijen, Kec.Semarang Timur \\
\hline \multicolumn{2}{l}{ Sumber: Analisis Penulis, 2018 } & &
\end{tabular}

Sumber: Analisis Penulis, 2018 


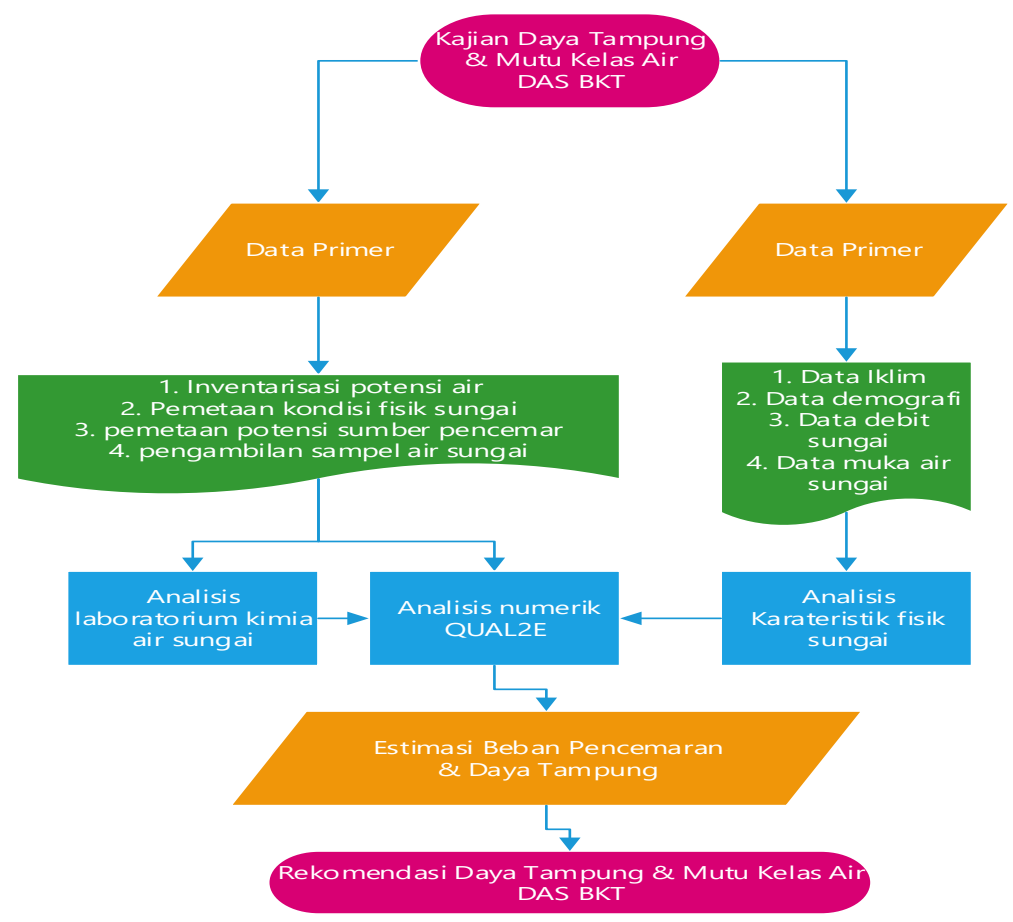

Gambar 1. Kerangka Analisis Kajian Daya Tampung dan Mutu Kelas Air DAS BKT

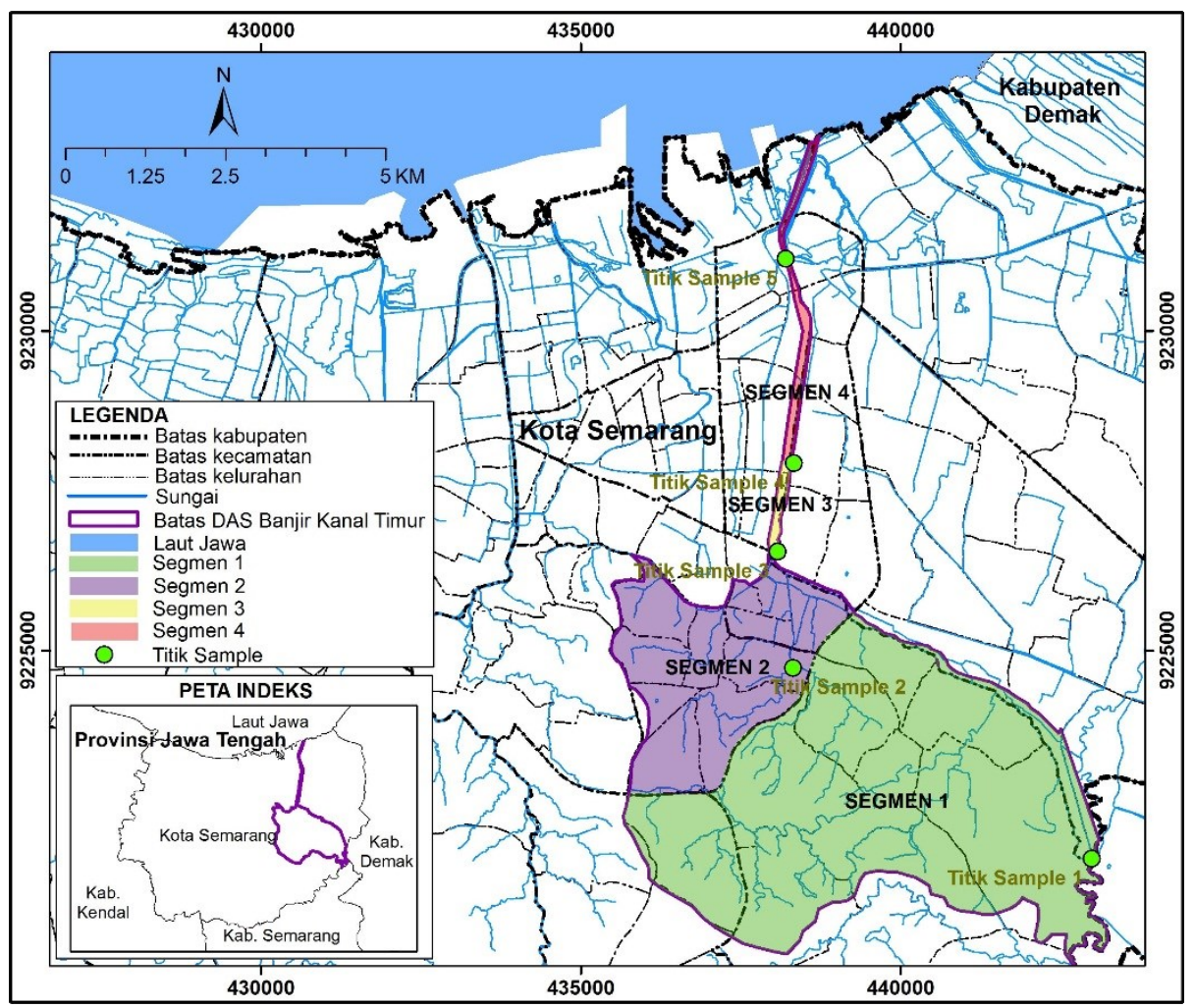

Sumber: Analisis Penulis, 2018

Gambar 2. Lokasi Pengambilan Sampel Air dan Segmen di DAS BKT 


\section{Hasil dan Pembahasan}

\section{Potensi Air Tanah di DAS BKT}

Potensi air tanah di daerah penelitian diperoleh dari sumur gali (dangkal) dan mata air. Pada daerah penelitian dilakukan pengukuran sebanyak delapan belas titik sumur gali dan tiga titik mata air. Pengukuran sumur gali dilakukan dengan kedalaman muka air tanah, sedangkan pengukuran mata air dilakukan dengan mengukur debit aliran mata air. Dari hasil pengukuran debit mata air, diperoleh hasil 0,1 L/dtk. Dari hasil pengukuran kedalaman muka air tanah didapatkan hasil interpolasi yang menunjukkan arah aliran air tanah mengalir dari selatan daerah penelitian ke arah utara daerah penelitian. Daerah penelitian pada daerah selatan memiliki elevasi lebih tinggi daripada daerah selatan. Hal ini dapat disimpulkan bahwa arah aliran air tanah di daerah penelitian mengalir dari daerah dengan elevasi yang tinggi menuju daerah dengan elevasi lebih rendah. Hal ini mengakibatkan kondisi kedalaman muka air tanah di daerah dengan elevasi yang lebih tinggi cenderung lebih dalam apabila dibandingkan dengan kedalaman muka air tanah pada daerah dengan elevasi rendah. Gambar 3 menunjukkan potensi air tanah pada DAS BKT dan Gambar 4 menunjukkan peta kontur muka air tanah (MAT) pada DAS BKT.

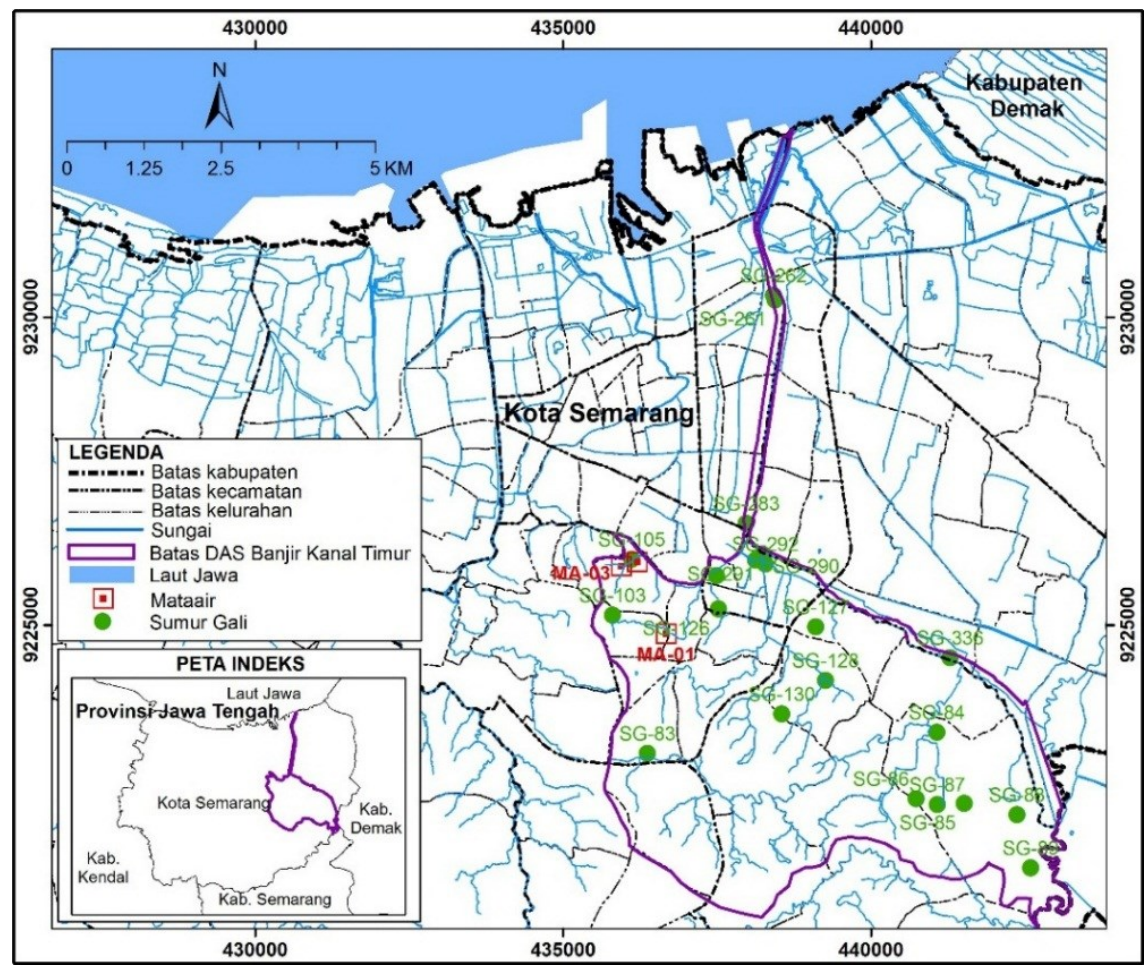

Sumber: Analisis Penulis, 2018

Gambar 3. Peta Potensi Air Tanah pada DAS BKT

\section{Hasil Analisis Kualitas Air DAS BKT}

Analisis kualitas air DAS BKT menggunakan parameter fisika dan kimia serta bakteriologi hasil laboratorium yang dibandingkan dengan Peraturan Pemerintah Nomor 82 Tahun 2001. Baku mutu yang digunakan adalah baku mutu air permukaan kelas II. Hasil analisis kualitas air DAS BKT disajikan pada Tabel 2. 
Tabel 2. Hasil Analisis Kualitas Air DAS BKT

\begin{tabular}{|c|c|c|c|c|c|c|c|c|c|c|}
\hline Titik & \multicolumn{2}{|c|}{$\begin{array}{c}\text { DO } \\
(\mathrm{mg} / \mathrm{L})\end{array}$} & \multicolumn{2}{|c|}{$\begin{array}{c}\text { BOD } \\
(\mathrm{mg} / \mathrm{L})\end{array}$} & \multicolumn{2}{|c|}{$\begin{array}{c}\mathrm{NO}_{3} \\
(\mathrm{mg} / \mathrm{L})\end{array}$} & \multicolumn{2}{|c|}{$\begin{array}{c}\mathrm{NO}_{2} \\
(\mathrm{mg} / \mathrm{L})\end{array}$} & \multicolumn{2}{|c|}{$\begin{array}{c}\text { fecal colifirm } \\
(\text { per } 100 \mathrm{ml})\end{array}$} \\
\hline Titik 1 & 6,36 & \multirow{5}{*}{4} & 2,1 & \multirow{5}{*}{3} & 1,98 & \multirow{5}{*}{10} & 0,050 & \multirow{5}{*}{0,06} & $>2.400$ & \multirow{5}{*}{1.000} \\
\hline Titik 2 & 0 & & 46 & & $\leq 0,23$ & & 0,006 & & 21 & \\
\hline Titik 3 & 0,16 & & 46 & & $\leq 0,23$ & & 0,004 & & 93 & \\
\hline Titik 4 & 1,93 & & 7,1 & & $\leq 0,23$ & & 0,016 & & $>2.400$ & \\
\hline Titik 5 & 0,24 & & 14 & & $\leq 0,23$ & & 0,006 & & 1.100 & \\
\hline
\end{tabular}

Sumber: Analisis Penulis, 2018

Keterangan:

\begin{tabular}{|l|l}
\hline & : Memenuhi Kelas II \\
\cline { 1 - 1 } & : Tidak Memenuhi Kelas II \\
& : Baku Mutu Air (PP No. 82 Tahun 2001)
\end{tabular}

Hasil uji parameter DO dan BOD menunjukkan hanya sampel titik 1 yang memenuhi baku mutu kelas II. Hal ini karena lokasi titik 1 merupakan daerah hulu dengan sumber pencemar di wilayah tersebut masih rendah, sedangkan titik lainnya tidak memenuhi baku mutu kelas II, dikarenakan banyaknya sumber pencemar yang masuk ke dalam sungai pada daerah lokasi sampling. Baku mutu oksigen terlarut memiliki karakteristik, apabila semakin besar konsentrasinya maka semakin baik kualitas airnya, akibatnya penurunan konsentrasi oksigen berdampak buruk bagi kehidupan air yang membutuhkan oksigen (Yuwono \& Setyobudiarso, 2016). Secara keseluruhan DAS BKT memiliki kualitas air yang buruk bila ditinjau dari parameter DO. Tingginya BOD ini disebabkan oleh air buangan rumah tangga dan industri. Hasil buangan tersebut menyebabkan mikroba menjadi aktif dan menguraikan barang organik menjadi asam-asam organik sehingga, BOD semakin tinggi (Herlambang, 2006). Secara keseluruhan sungai BKT memiliki kualitas air yang buruk jika ditinjau dari parameter DO dan BOD.

Hasil uji parameter $\mathrm{NO}_{3}$ dan $\mathrm{NO}_{2}$ menunjukkan bahwa di DAS BKT memenuhi baku mutu air kelas II, nilai konsentrasi untuk $\mathrm{NO}_{3}$ jauh dibawah baku mutu yaitu $10 \mathrm{mg} / \mathrm{L}$ dan nilai konsentrasi untuk $\mathrm{NO}_{2}$ dibawah baku mutu yaitu 0,06 mg/L. Rendahnya nilai konsentrasi nitrat dan nitrit dikarenakan sedikitnya lahan pertanian di DAS BKT. Lahan pertanian hanya terdapat pada daerah hulu (titik 1) sehingga nilai konsentrasi nitrat tertinggi terdapat pada titik 1 . Secara keseluruhan sungai BKT memiliki kualitas air yang baik jika ditinjau dari parameter $\mathrm{NO}_{3}$ dan $\mathrm{NO}_{2}$.

Hasil uji parameter fecal colifirm menunjukkan bahwa fecal coliform di DAS BKT yang memenuhi baku mutu air kelas II yaitu titik 2 dan titik 3, nilai konsentrasi di bawah baku mutu yaitu 1.000 jumlah/100 ml. Limpasan air dari sawah dan tinja yang dihasilkan oleh manusia dan peternakan dapat memicu meningkatnya jumlah fecal coliform. Secara keseluruhan DAS BKT memiliki kualitas air yang buruk jika ditinjau dari parameter fecal coliform.

\section{Inventarisasi Sumber Pencemaran}

Hasil perhitungan estimasi beban cemaran dan debit limbah domestik setiap segmen di DAS BKT pada tahun 2017 ditunjukkan pada Tabel 3. 
Tabel 3. Hasil Perhitungan Estimasi Beban Cemaran dan Debit Limbah Domestik DAS BKT

\begin{tabular}{|c|c|c|c|c|c|c|c|}
\hline \multirow[b]{2}{*}{ Segmen } & \multirow[b]{2}{*}{$\begin{array}{c}\text { Jumlah } \\
\text { Penduduk } \\
\text { (jiwa) }\end{array}$} & \multicolumn{6}{|c|}{ Beban Cemaran Domestik (kg/hari) } \\
\hline & & $\begin{array}{c}\text { Total } \\
\text { Suspended } \\
\text { Solid } \\
\text { (TSS) } \\
\end{array}$ & BOD & COD & $\begin{array}{c}\text { Minyak } \\
\text { dan } \\
\text { lemak }\end{array}$ & Detergen & $\mathbf{N H}_{4}$ \\
\hline 1 & 222.202 & $6.860,50$ & $7.221,58$ & $9.929,67$ & 220,26 & 34,12 & 324,97 \\
\hline 2 & 166.272 & $5.133,64$ & $5.403,83$ & $7.430,27$ & 1,35 & 243,17 & 243,17 \\
\hline 3 & 100.470 & $3.102,01$ & $3.265,28$ & $4.489,75$ & 0,82 & 146,94 & 146,94 \\
\hline 4 & 89.269 & $2.756,19$ & $2.901,25$ & $3.989,22$ & 0,73 & 130,56 & 130,56 \\
\hline \multirow[b]{2}{*}{ Segmen } & Jumlah & \multicolumn{6}{|c|}{ Beban Cemaran Domestik (kg/hari) } \\
\hline & $\begin{array}{c}\text { Penduduk } \\
\text { (jiwa) }\end{array}$ & $\mathrm{NO}_{2}$ & $\mathrm{NO}_{3}$ & Total $\mathbf{N}$ & $\mathrm{PO}_{4}$ & $\mathbf{P}$ & $\begin{array}{c}\text { Fecal } \\
\text { Coliform }\end{array}$ \\
\hline 1 & 222.202 & 0,36 & 1,81 & 352,05 & 30,69 & 37,91 & $5,42 \times 10^{16}$ \\
\hline 2 & 166.272 & 0,27 & 1,35 & 263,44 & 22,97 & 28,37 & $4,053 \times 10^{16}$ \\
\hline 3 & 100.470 & 0,16 & 0,82 & 159,18 & 13,88 & 17,14 & $2,45 \times 10^{16}$ \\
\hline 4 & 89.269 & 0,15 & 0,73 & 141,44 & 12,33 & 15,23 & $2,18 \times 10^{16}$ \\
\hline
\end{tabular}

Sumber: Analisis Penulis, 2018

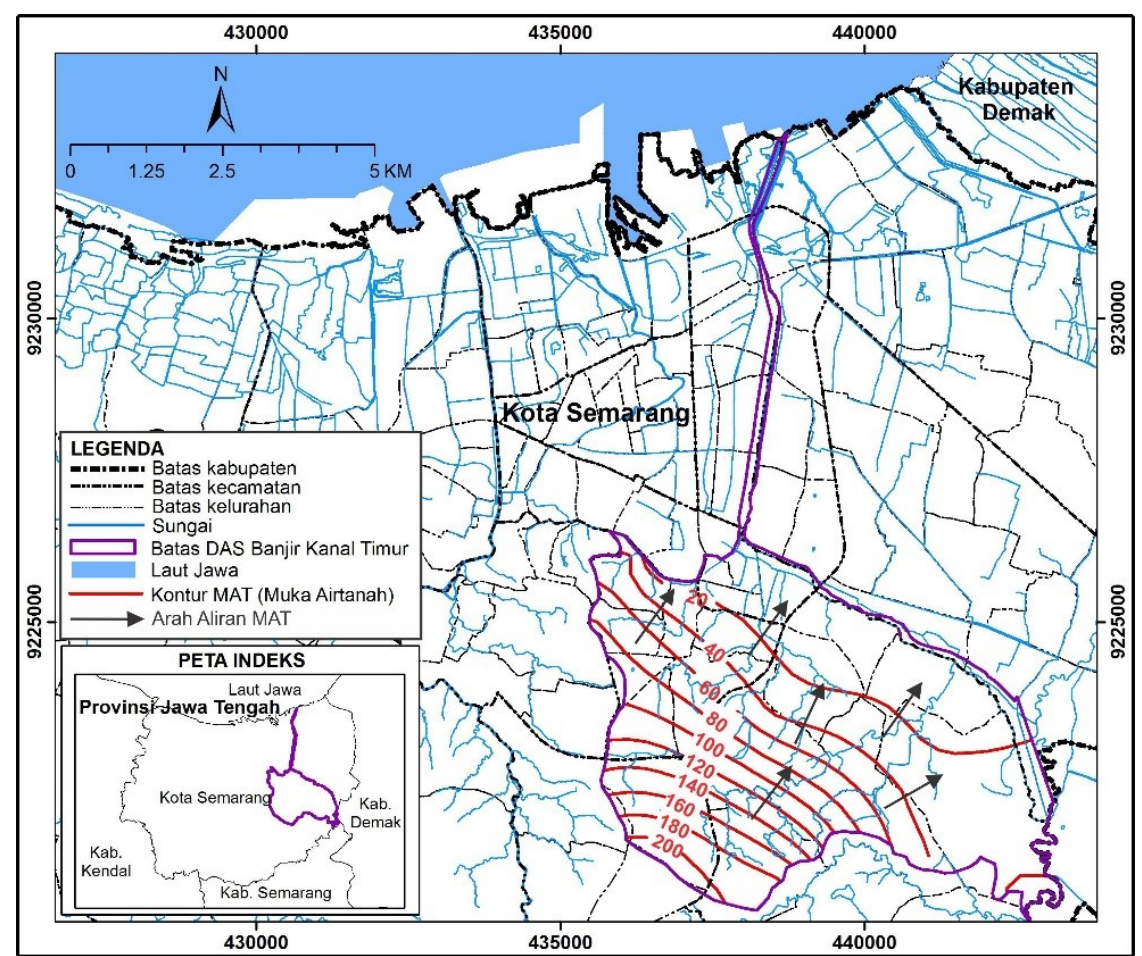

Sumber: Analisis Penulis, 2018

\section{Gambar 4. Peta Kontur MAT pada DAS BKT}

Hasil perhitungan estimasi beban cemaran domestik serta jumlah debit limbah domestik DAS BKT pada tahun 2017, yang memiliki nilai terbesar ada pada segmen 1. Hal ini dikarenakan pada segmen 1 terdapat banyak penduduk yang berada di segmen tersebut dibandingkan dengan segmen yang lain. Jumlah penduduk yang tinggi akan 
mengakibatkan konsentrasi pencemar yang tinggi juga akibat permukiman di sekitar sungai dan limbah domestik maupun limbah cair rumah tangga yang dihasilkan (Samudro, Agustiningsih, \& Sasongko, 2012). Demikian juga sebaliknya jumlah penduduk yang rendah maka konsentrasi pencemar sungai di segmen tersebut akan rendah juga, dipengaruhi oleh banyaknya limbah cair yang dihasilkan oleh rumah tangga.

Limbah pertanian sangat berpengaruh terhadap konsentrasi pencemar dalam perairan sungai. Oleh sebab itu, limbah pertanian juga diperhitungkan dalam perhitungan parameter beban pencemaran. Limbah pertanian di sekitar DAS BKT didominasi oleh limpasan aliran dari irigasi lahan sawah. Limbah ini mengandung berbagai macam senyawa kimia hasil dari penggunaan pupuk dan pestisida untuk kepentingan pertanian (Kementerian Lingkungan Hidup Republik Indonesia, 2010). Kuantitas limbah pertanian dipengaruhi oleh luas lahan sawah di sepanjang sungai yang pembuangannya langsung ke sungai dan tidak dilakukan pengolahan terlebih dahulu. Lahan pertanian hanya terdapat di segmen 1 yaitu sebesar 15,95 ha. Tabel 4 menunjukkan hasil perhitungan estimasi beban cemaran pertanian DAS BKT. Dari hasil perhitungan diperoleh estimasi beban cemaran pertanian DAS BKT antara lain: COD sebesar 0,07975 kg/ha/hari; BOD sebesar 9,97 $\mathrm{kg} / \mathrm{ha} / \mathrm{hari}$; N sebesar 0,87 kg/ha/hari; P sebesar 0,44 kg/ha/hari; TSS sebesar 0,00 $\mathrm{kg} / \mathrm{ha} / \mathrm{hari}$; Petisida sebesar 0,01 L/ha/hari; limbah debit pertanian sebesar 0,0002 L/dtk.

Selain limbah pertanian, limbah peternakan juga mempengaruhi konsentrasi pencemar sungai, yaitu pada lokasi penelitian terdapat peternakan. Tabel 5 menunjukkan hasil perhitungan estimasi beban cemaran peternakan DAS BKT.

Tabel 4. Estimasi Beban Cemaran Pertanian DAS BKT

\begin{tabular}{|c|c|c|c|c|c|c|c|c|}
\hline \multirow[b]{2}{*}{ Segmen } & \multirow{2}{*}{$\begin{array}{c}\text { Luas } \\
\text { Lahan } \\
\text { sawah } \\
\text { (ha) }\end{array}$} & \multicolumn{6}{|c|}{ Beban Pencemaran Pertanian (sawah) } & \multirow{2}{*}{$\begin{array}{c}\text { Debit } \\
\text { Limbah } \\
\text { Pertanian } \\
\text { (L/detik) }\end{array}$} \\
\hline & & $\begin{array}{c}\text { COD } \\
\text { (kg/ha/ } \\
\text { hari) }\end{array}$ & $\begin{array}{c}\text { BOD } \\
\text { (kg/ha/ } \\
\text { hari) }\end{array}$ & $\begin{array}{c}\mathrm{N} \\
\text { (kg/ha/ } \\
\text { hari) }\end{array}$ & $\begin{array}{c}P \\
\text { (kg/ha/ } \\
\text { hari) }\end{array}$ & $\begin{array}{c}\text { TSS } \\
\text { (kg/ha/ } \\
\text { hari) }\end{array}$ & $\begin{array}{c}\text { Pestisida } \\
\text { (L/Ha } \\
\text { /hari) }\end{array}$ & \\
\hline 1 & 15,95 & 0,07975 & 9,97 & 0,87 & 0,44 & 0,00 & 0,01 & 0,0002 \\
\hline
\end{tabular}

Tabel 5. Estimasi Beban Cemaran Perternakan DAS BKT

\begin{tabular}{ccccccccccc}
\hline \multirow{2}{*}{ Segmen } & \multicolumn{7}{c}{ Beban Cemaran Peternakan Segmen 2 (gr/ekor/hari) } \\
\cline { 2 - 10 } & TSS & BOD & COD & NO & NO3 & NH $_{4}$ & N-Total & P-Total & $\begin{array}{c}\text { Fecal } \\
\text { Coliform }\end{array}$ \\
\hline Segmen 1 & 81,582 & 152,02 & 376,07 & 0,005 & 0,17 & 2,36 & 26,931 & 0,284 & $4,26 \times 10^{9}$ \\
Segmen 2 & 6,42 & $5,833,17$ & $15.388,67$ & 0,002 & 0,08 & 1,282 & 1,438 & 0,133 & $2,36 \times 10^{9}$ \\
Segmen 3 & 1,57 & 9,844 & 24,725 & 0,0003 & 0,011 & 0,172 & 0,19 & 0,021 & $3,39 \times 10^{8}$ \\
Segmen 4 & 2,4738 & 17,4431 & 44,26633 & 0,0007 & 0,0225 & 0,36 & 0,402 & 0,0398 & $6,53 \times 10^{8}$ \\
\hline \multicolumn{2}{c}{ Sumber: Analisis Penulis, 2018 } & & & & & & &
\end{tabular}

Berdasarkan hasil perhitungan diperoleh hasil estimasi beban cemaran limbah peternakan yang menunjukkan bahwa segmen 1 penghasil limbah peternakan terbesar. Hal ini, karena pada segmen 1 terdapat berbagai jenis ternak dalam jumlah yang banyak jika dibandingkan dengan segmen yang lainnya. Dari perhitungan beban cemaran pada sektor peternakan, semua segmen DAS BKT memiliki potensi beban cemaran paling besar yaitu parameter COD. COD ini tinggi dapat diakibatkan dari makanan ternak dan kadar oksigen yang rendah menyebabkan COD tinggi. Selain itu, potensi beban cemaran lainnya adalah 
fecal coliform. Parameter ini dapat langsung diketahui berasal dari kotoran-kotoran hewan ternak yang dibuang ke sungai, atau adanya aliran air permukaan (runoff) membawa kotoran hewan ternak menuju badan sungai.

Potensi beban pencemaran lain berasal dari limbah industri yang terdapat di DAS BKT. Berdasarkan survei dan observasi yang telah dilakukan di DAS BKT terdapat berbagai jenis industri. Limbah industri yang dibuang ke sungai tanpa pengolahan yang baik, berpengaruh terhadap tingginya kadar BOD pada air sungai (Puspitasari, 2009). Jenis industri yang ada di sepanjang DAS BKT antara lain industri seng dan baja, industri makanan seperti tahu, tempe, kacang atom dan tepung terigu, serta industri plastik.

\section{Beban Pencemaran Menggunakan Pemodelan QUAL2E}

Parameter simulasi model yang dipergunakan adalah $\mathrm{BOD}, \mathrm{DO}, \mathrm{NO}_{3}, \mathrm{NO}_{2}$, dan fecal coliform. Hasil pengolahan data serta perhitungan kemudian dimasukkan ke dalam program QUAL2E.

BOD Sungai Banjir Kanal Timur (Concentration)

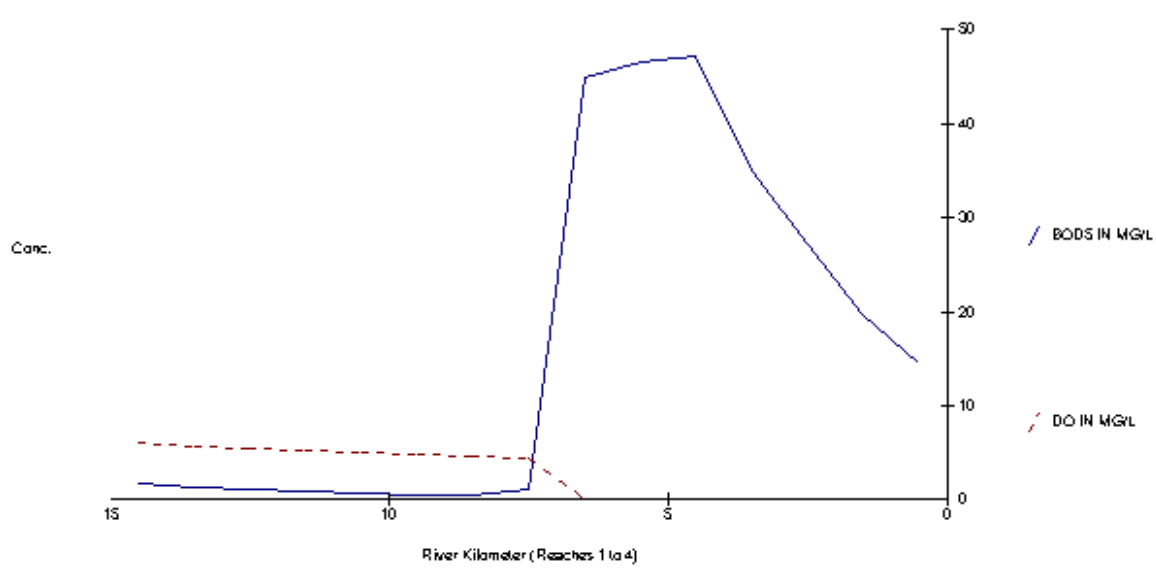

Sumber: Analisis Penulis, 2018

Gambar 5. Grafik Hasil Running Permodelan QUAL2E Parameter BOD dan DO

Berdasarkan hasil running (Gambar 5) dapat dilihat bahwa konsentrasi model BOD mengalami fluktuasi dari hulu hingga hilir yang ditunjukkan dengan garis biru. Kenaikan konsentrasi BOD disebabkan oleh adanya masukan dari beban pencemaran domestik pertanian dan industri, sedangkan penurunan konsentrasi BOD disebabkan oleh kemungkinan adanya aerasi yang terjadi di sungai. Konsentrasi DO yang ditunjukkan dengan garis merah putus-putus mengalami penurunan dari hulu hingga hilir. Nilai konsentrasi DO berbanding terbalik dengan nilai konsentrasi BOD. Hal ini disebabkan oleh tingginya kebutuhan oksigen untuk mendegradasi bahan organik yang ada di dalam air. Semakin banyak bahan organik di dalam air, maka semakin besar BOD nya, sedangkan DO akan semakin rendah.

Berdasarkan hasil running (Gambar 6) dapat dilihat konsentrasi $\mathrm{NO}_{2}$ model yang ditunjukkan oleh garis warna biru dan konsentrasi $\mathrm{NO}_{3}$ yang ditunjukkan oleh garis merah putus - putus mengalami penurunan dari hulu hingga hilir. Konsentrasi nitrit dan nitrat tertinggi terdapat di titik 1 (hulu). Hal ini disebabkan karena jumlah input beban cemaran dari pertanian yang masuk ke Sungai BKT banyak terdapat pada daerah hulu. Pencemaran air dari nitrit dan nitrat bersumber dari tanah dan tanaman. Grafik tersebut menunjukkan bahwa di dalam perairan nitrit dan nitrat berbanding lurus tidak dapat dipisahkan. 


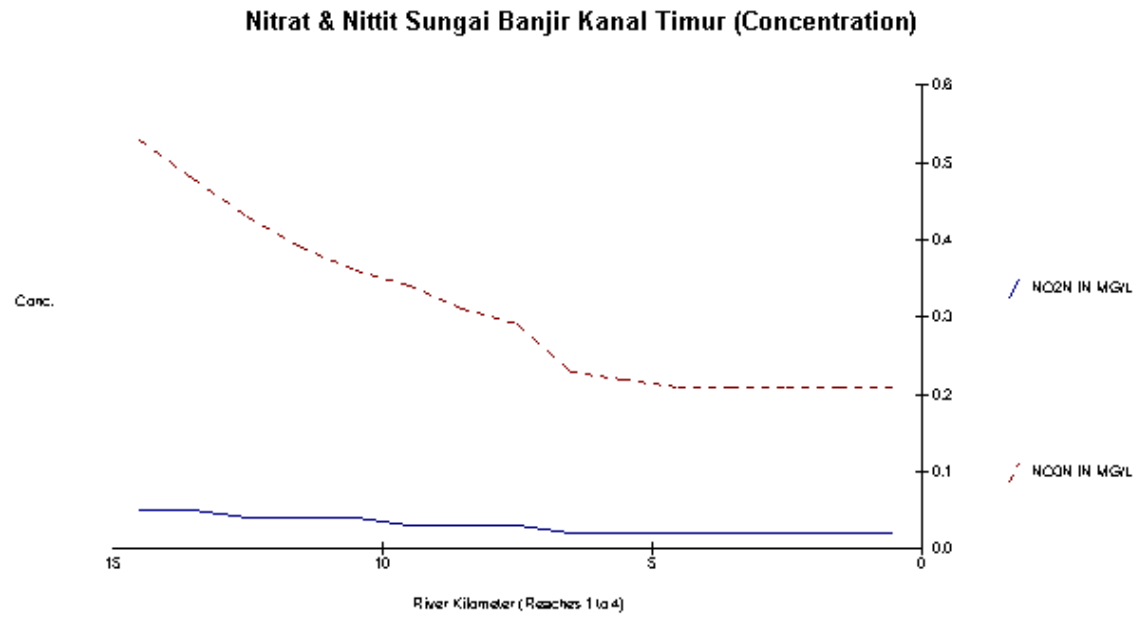

Sumber: Analisis Penulis, 2018

Gambar 6. Grafik Hasil Running Permodelan QUAL2E Parameter $\mathrm{NO}_{2}$ dan $\mathrm{NO}_{3}$

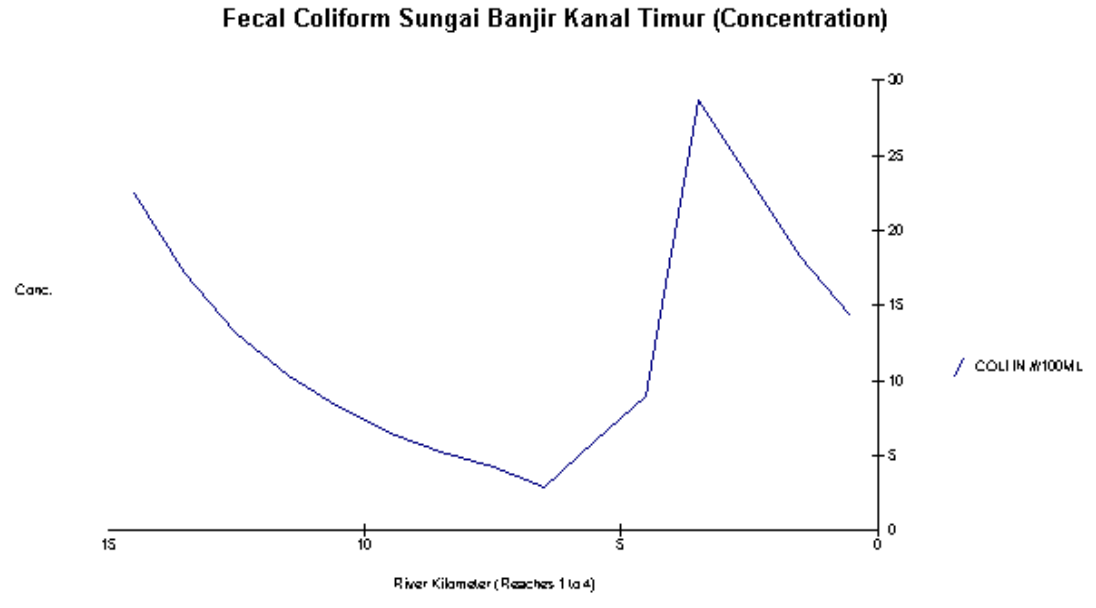

Sumber: Analisis Penulis, 2018

\section{Gambar 7. Grafik Hasil Running Permodelan QUAL2E Parameter $\mathrm{NO}_{2}$ dan $\mathrm{NO}_{3}$}

Pada Gambar 7, grafik hasil running menunjukkan bahwa jumlah bakteri model fecal coliform mengalami fluktuasi dari hulu hingga hilir ditunjukkan dengan garis biru. Jumlah bakteri tertinggi terdapat pada segmen 3 yang merupakan wilayah perkotaan dan padat penduduknya. Bakteri fecal coliform berasal dari sumber beban cemaran domestik dan limbah peternakan.

\section{Daya Tampung Beban Cemaran}

Hasil perhitungan daya tampung beban cemaran BOD di setiap segmen ditunjukkan pada Tabel 6. 
Tabel 6. Daya Tampung Beban Cemaran BOD pada Setiap Segmen

\begin{tabular}{|c|c|c|c|c|c|c|c|c|}
\hline Segmen & km & $\begin{array}{c}\text { Konsentrasi } \\
\text { BOD } \\
(\mathrm{mg} / \mathrm{L})\end{array}$ & $\begin{array}{l}\text { Debit } \\
\left(\mathrm{m}^{3} / \mathbf{s}\right)\end{array}$ & $\begin{array}{c}\text { Beban } \\
\text { Cemaran } \\
\text { BOD } \\
\text { (kg/hari) }\end{array}$ & $\begin{array}{c}\text { DTBP } \\
\text { Kelas I } \\
\text { (kg/hari) }\end{array}$ & $\begin{array}{c}\text { DTBP } \\
\text { Kelas II } \\
\text { (kg/hari) }\end{array}$ & $\begin{array}{c}\text { DTBP } \\
\text { Kelas III } \\
\text { (kg/hari) }\end{array}$ & $\begin{array}{c}\text { DTBP } \\
\text { Kelas IV } \\
\text { (kg/hari) }\end{array}$ \\
\hline \multirow[t]{9}{*}{1} & 15 & 1,69 & 8,49 & 1.240 & 227 & 960,9 & 3.162 & 7.563 \\
\hline & 14 & 1,36 & 8,49 & 998 & 469 & 1.203 & 3.404 & 7.805 \\
\hline & 13 & 1,10 & 8,49 & 807 & 660 & 1.394 & 3.594 & 7.996 \\
\hline & 12 & 0,89 & 8,49 & 653 & 814 & 1.548 & 3.748 & 8.150 \\
\hline & 11 & 0,71 & 0,25 & 15,5 & 28,1 & 49,86 & 115 & 246 \\
\hline & 10 & 0,58 & 0,25 & 12,6 & 30,9 & 52,7 & 118 & 249 \\
\hline & 9 & 0,47 & 0,25 & 10,2 & 33,3 & 55,1 & 120 & 251 \\
\hline & 8 & 1,04 & 0,25 & 22,6 & 20,9 & 42,7 & 108 & 239 \\
\hline & 7 & 45,0 & 0,25 & 979 & -936 & -914 & -848 & -718 \\
\hline \multirow[t]{2}{*}{2} & 6 & 46,6 & 2,04 & 8.208 & -7.856 & -7.679 & -7.151 & -6.093 \\
\hline & 5 & 47,2 & 2,04 & 8.321 & -7.969 & -7.792 & -7.264 & -6.206 \\
\hline 3 & 4 & 35,0 & 3,92 & 11.864 & -11.187 & -10.848 & -9.832 & -7.800 \\
\hline \multirow[t]{3}{*}{4} & 3 & 27,2 & 7,86 & 18.478 & -17.120 & -16.441 & -14.404 & -10.329 \\
\hline & 2 & 19,8 & 7,86 & 13.446 & -12.088 & -11.409 & -9.372 & -5.297 \\
\hline & 1 & 14,5 & 7,86 & 9.874 & -8.516 & -7.837 & -5.800 & -1.725 \\
\hline
\end{tabular}

Sumber: Analisis Penulis, 2018

Keterangan: DTBP: Daya Tampung Beban Pencemaran

Pada Tabel 6 dapat dilihat bahwa hanya segmen 1 yang masih memiliki daya tampung beban cemaran BOD sungai BKT. Beban cemaran yang masuk ke sungai belum melewati batas beban cemaran yang diizinkan untuk setiap kelasnya. Hal ini dikarenakan segmen 1 yang berada di daerah hulu, tingkat pencemarnya masih rendah jika dibandingkan dengan hilir. Pada segmen 1 beban cemaran tertinggi yang masuk ke sungai terdapat di kilometer 15 yaitu sebesar $1.240 \mathrm{~kg} / \mathrm{hari}$ dengan daya tampung beban cemaran BOD untuk kelas II sebesar $961 \mathrm{~kg} /$ hari, sedangkan pada segmen 2 hingga segmen 4, daya tampung beban cemaran BOD sudah melebihi batas. Tabel 7 menunjukkan hasil perhitungan daya tampung beban cemaran $\mathrm{NO}_{2}$ di setiap segmen.

Hasil perhitungan menunjukkan bahwa semua segmen mampu menampung beban cemaran $\mathrm{NO}_{2}$. Beban pencemaran $\mathrm{NO}_{2}$ tertinggi terdapat pada awal segmen 1. Meskipun demikian, pada awal segmen 1 masih memiliki daya tampung beban cemaran $\mathrm{NO}_{2}$ sebesar 7,34 kg/hari. Daya tampung beban cemaran tertinggi terdapat pada segmen 4 yaitu sebesar 27,2 kg/hari. Pada segmen 4 yang merupakan daerah hilir, lahan pertanian tidak ditemukan. Hal ini yang menjadi salah satu faktor sungai BKT pada segmen 4 masih memiliki daya tampung beban cemaran $\mathrm{NO}_{2}$ yang besar.

Tabel 8 menunjukkan bahwa beban pencemaran $\mathrm{NO}_{3}$ tertinggi terdapat pada awal segmen 1 namun masih memiliki daya tampung beban cemaran $\mathrm{NO}_{3}$ untuk kelas I dan II sebesar $6.947 \mathrm{~kg} /$ hari dan untuk kelas III dan IV sebesar $14.282 \mathrm{~kg} / \mathrm{hari} . \mathrm{NO}_{3}$ yang ada di hulu dapat berasal dari pupuk pertanian yang digunakan di sekitar DAS BKT. Biasanya pupuk yang digunakan mengandung kandungan $\mathrm{NO}_{3}$ yang dapat menyuburkan tanaman Papilionaceae (suku polong-polongan). 
Tabel 7. Daya Tampung Beban Cemaran $\mathrm{NO}_{2}$ pada Setiap Segmen

\begin{tabular}{|c|c|c|c|c|c|c|c|c|}
\hline Segmen & km & $\begin{array}{l}\text { Konsentrasi } \\
\text { Nitrit }\left(\mathrm{NO}_{2}\right)\end{array}$ & $\begin{array}{l}\text { Debit } \\
\left(\mathrm{m}^{3} / \mathbf{s}\right)\end{array}$ & $\begin{array}{c}\text { Beban } \\
\text { Cemaran } \\
\text { Nitrit }\left(\mathrm{NO}_{2}\right) \\
(\mathrm{kg} / \mathrm{hari}) \\
\end{array}$ & $\begin{array}{c}\text { DTBP } \\
\text { Kelas I } \\
\text { (kg/hari) }\end{array}$ & $\begin{array}{c}\text { DTBP } \\
\text { Kelas II } \\
\text { (kg/hari) }\end{array}$ & $\begin{array}{c}\text { DTBP } \\
\text { Kelas III } \\
\text { (kg/hari) }\end{array}$ & $\begin{array}{c}\text { DTBP } \\
\text { Kelas IV } \\
\text { (kg/hari) }\end{array}$ \\
\hline \multirow[t]{9}{*}{1} & 15 & 0,05 & 8,49 & 36,7 & 7,34 & 7,34 & 7,34 & - \\
\hline & 14 & 0,05 & 8,49 & 36,7 & 7,34 & 7,34 & 7,34 & - \\
\hline & 13 & 0,04 & 8,49 & 29,3 & 14,7 & 14,7 & 14,7 & - \\
\hline & 12 & 0,04 & 8,49 & 29,3 & 14,7 & 14,7 & 14,7 & - \\
\hline & 11 & 0,04 & 0,25 & 0,87 & 0,44 & 0,44 & 0,44 & - \\
\hline & 10 & 0,03 & 0,25 & 0,65 & 0,65 & 0,65 & 0,65 & - \\
\hline & 9 & 0,03 & 0,25 & 0,65 & 0,65 & 0,65 & 0,65 & - \\
\hline & 8 & 0,03 & 0,25 & 0,65 & 0,65 & 0,65 & 0,65 & - \\
\hline & 7 & 0,02 & 0,25 & 0,44 & 0,87 & 0,87 & 0,87 & - \\
\hline \multirow[t]{2}{*}{2} & 6 & 0,02 & 2,04 & 3,53 & 7,05 & 7,05 & 7,05 & - \\
\hline & 5 & 0,02 & 2,04 & 3,53 & 7,05 & 7,05 & 7,05 & - \\
\hline 3 & 4 & 0,02 & 3,92 & 6,77 & 13,55 & 13,55 & 13,55 & - \\
\hline \multirow[t]{3}{*}{4} & 3 & 0,02 & 7,86 & 13,58 & 27,16 & 27,16 & 27,16 & - \\
\hline & 2 & 0,02 & 7,86 & 13,58 & 27,16 & 27,16 & 27,16 & - \\
\hline & 1 & 0,02 & 7,86 & 13,58 & 27,16 & 27,16 & 27,16 & - \\
\hline
\end{tabular}

Sumber: Analisis Penulis, 2018

Keterangan: DTBP: Daya Tampung Beban Pencemaran

Tabel 8. Daya Tampung Beban Cemaran $\mathrm{NO}_{3}$ Pada Setiap Segmen

\begin{tabular}{|c|c|c|c|c|c|c|c|c|}
\hline Segmen & km & $\begin{array}{l}\text { Konsentrasi } \\
\mathrm{NO}_{3}(\mathrm{mg} / \mathrm{L})\end{array}$ & $\begin{array}{l}\text { Debit } \\
\left(\mathrm{m}^{3} / \mathrm{s}\right)\end{array}$ & $\begin{array}{c}\text { Beban } \\
\text { Cemaran } \\
\mathrm{NO}_{3}(\mathrm{~kg} / \mathrm{hari})\end{array}$ & $\begin{array}{c}\text { DTBP } \\
\text { Kelas I } \\
\text { (kg/hari) }\end{array}$ & $\begin{array}{c}\text { DTBP } \\
\text { Kelas II } \\
\text { (kg/hari) }\end{array}$ & $\begin{array}{c}\text { DTBP } \\
\text { Kelas III } \\
\text { (kg/hari) }\end{array}$ & $\begin{array}{c}\text { DTBP } \\
\text { Kelas IV } \\
\text { (kg/hari) }\end{array}$ \\
\hline \multirow[t]{9}{*}{1} & 15 & 0,53 & 8,49 & 389 & 6.947 & 6.947 & 14.282 & 14.282 \\
\hline & 14 & 0,48 & 8,49 & 352 & 6.983 & 6.983 & 14.319 & 14.319 \\
\hline & 13 & 0,43 & 8,49 & 315 & 7.020 & 7.020 & 14.355 & 14.355 \\
\hline & 12 & 0,39 & 8,49 & 286 & 7.049 & 7.049 & 14.385 & 14.385 \\
\hline & 11 & 0,36 & 0,252 & 7,84 & 210 & 210 & 428 & 427 \\
\hline & 10 & 0,34 & 0,252 & 7,40 & 210 & 210 & 428 & 428 \\
\hline & 9 & 0,37 & 0,252 & 8,06 & 210 & 210 & 427 & 427 \\
\hline & 8 & 0,34 & 0,252 & 7,40 & 210 & 210 & 428 & 428 \\
\hline & 7 & 0,32 & 0,252 & 6,97 & 211 & 211 & 428 & 428 \\
\hline \multirow[t]{2}{*}{2} & 6 & 0,25 & 2,04 & 44,1 & 1.719 & 1.719 & 3.481 & 3.481 \\
\hline & 5 & 0,22 & 2,04 & 38,8 & 1.724 & 1.724 & 3.486 & 3.486 \\
\hline 3 & 4 & 0,21 & 3,92 & 71,1 & 3.316 & 3.316 & 6.703 & 6.703 \\
\hline \multirow[t]{3}{*}{4} & 3 & 0,21 & 7,86 & 142,6 & 6.648 & 6.648 & 13.439 & 13.439 \\
\hline & 2 & 0,21 & 7,86 & 142,6 & 6.648 & 6.648 & 13.439 & 13.439 \\
\hline & 1 & 0,21 & 7,86 & 142,6 & 6.648 & 6.648 & 13.439 & 13.439 \\
\hline
\end{tabular}


Berdasarkan Tabel 8 dapat dilihat bahwa walaupun beban cemaran $\mathrm{NO}_{3}$ rendah namun jika debit sungai rendah maka daya tampung beban cemaran $\mathrm{NO}_{3}$ juga akan rendah. Seperti pada akhir segmen 1 yang memiliki beban cemaran $\mathrm{NO}_{3}$ sebesar $6,97 \mathrm{~kg} / \mathrm{hari}$ dengan debit eksisting $0,25 \mathrm{~m}^{3} /$ dtk memiliki daya tampung beban cemaran $\mathrm{NO}_{3}$ terendah yaitu sebesar $211 \mathrm{~kg} /$ hari untuk kelas I dan II sedangkan untuk kelas III dan IV sebesar $427 \mathrm{~kg} / \mathrm{hari}$.

Pada Tabel 9 dapat dilihat bahwa daya tampung Sungai BKT pada segmen 1 tidak dapat menampung beban cemaran fecal coliform. Beban cemaran yang masuk ke sungai telah melewati batas beban cemaran yang diizinkan untuk setiap kelasnya. Meskipun segmen 1 berada di daerah hulu namun untuk beban cemaran fecal coliform yang masuk ke sungai sangat tinggi. Bakteri fecal coliform berasal dari tinja manusia dan peternakan. Berdasarkan data sekunder diketahui bahwa di segmen 1 terdapat banyak peternakan dan jumlah penduduk yang paling banyak di antara segmen lainnya. Pada segmen 1 beban cemaran tertinggi yang masuk ke sungai terdapat di kilometer 15 yaitu sebesar 2.247 jumlah/100 ml dengan daya tampung beban cemaran BOD untuk kelas II sebesar -9,15 x $1.012 \mathrm{~kg} / \mathrm{hari}$. Tanda negatif menunjukkan bahwa Sungai BKT di segmen tidak memiliki daya tampung beban cemaran fecal coliform.

Pada segmen 2 masih dapat menampung beban cemaran fecal coliform. Beban cemaran yang masuk ke sungai belum melewati batas beban cemaran yang diizinkan untuk setiap kelasnya. Masyarakat yang berada di daerah segmen 2 yaitu kawasan perkotaan, sadar akan pentingnya sanitasi. Hampir semua penduduk memiliki septic tank sehingga tingkat cemaran fecal coliform yang masuk ke sungai rendah. Sungai BKT pada segmen 2 kilometer 6 masih memiliki daya tampung beban cemaran fecal coliform untuk kelas II sebesar 1,6 x 1.021 jumlah/hari sedangkan kilometer 5 memiliki daya tampung beban cemaran fecal coliform untuk kelas II sebesar 1,73 x 1.011 jumlah/hari.

Tabel 9. Daya Tampung Beban Cemaran Fecal Coliform pada Setiap Segmen

\begin{tabular}{ccccccccc}
\hline Segmen & $\mathbf{k m}$ & $\begin{array}{c}\text { Konsentrasi } \\
\boldsymbol{F C}\end{array}$ & $\begin{array}{c}\text { Debit } \\
\left(\mathbf{m}^{3} / \mathbf{s}\right)\end{array}$ & $\begin{array}{c}\text { Beban } \\
\text { Cemaran } \boldsymbol{F C} \\
(\mathbf{j m l} / \mathbf{h a r i})\end{array}$ & $\begin{array}{c}\text { DTBP } \\
\text { Kelas I } \\
(\mathbf{j m l} / \mathbf{h a r i})\end{array}$ & $\begin{array}{c}\text { DTBP } \\
\text { Kelas II } \\
(\mathbf{j m l} / \mathbf{h a r i})\end{array}$ & $\begin{array}{c}\text { DTBP } \\
\text { Kelas III } \\
(\mathbf{j m l} / \mathbf{h a r i})\end{array}$ & $\begin{array}{c}\text { DTBP } \\
\text { Kelas IV } \\
(\mathbf{j m l} / \mathbf{h a r i})\end{array}$ \\
\hline 1 & 15 & 2.247 & 8,49 & $1,65 \times 10^{13}$ & $-1,57 \times 10^{13}$ & $-9,15 \times 10^{12}$ & $-1,81 \times 10^{12}$ & $-1,81 \times 10^{12}$ \\
& 14 & 1.712 & 8,49 & $1,256 \times 10^{13}$ & $-1,18 \times 10^{13}$ & $-5,22 \times 10^{12}$ & $2,11 \times 10^{12}$ & $2,11 \times 10^{12}$ \\
& 13 & 1.323 & 8,49 & $9,705 \times 10^{12}$ & $-8,97 \times 10^{12}$ & $-2,37 \times 10^{12}$ & $4,97 \times 10^{12}$ & $4,97 \times 10^{12}$ \\
& 12 & 1.035 & 8,49 & $7,592 \times 10^{12}$ & $-6,86 \times 10^{12}$ & $-2,57 \times 10^{11}$ & $7,08 \times 10^{12}$ & $7,08 \times 10^{12}$ \\
& 11 & 818 & 0,252 & $1,781 \times 10^{11}$ & $-1,56 \times 10^{11}$ & $3,96 \times 10^{10}$ & $2,57 \times 10^{11}$ & $2,57 \times 10^{11}$ \\
& 10 & 652 & 0,252 & $1,420 \times 10^{11}$ & $-1,20 \times 10^{11}$ & $7,58 \times 10^{10}$ & $2,93 \times 10^{11}$ & $2,93 \times 10^{11}$ \\
& 9 & 523 & 0,252 & $1,139 \times 10^{11}$ & $-9,21 \times 10^{10}$ & $1,04 \times 10^{11}$ & $3,22 \times 10^{11}$ & $3,22 \times 10^{11}$ \\
& 8 & 422 & 0,252 & $9,188 \times 10^{10}$ & $-7,01 \times 10^{10}$ & $1,26 \times 10^{11}$ & $3,44 \times 10^{11}$ & $3,44 \times 10^{11}$ \\
& 7 & 296 & 0,252 & $6,445 \times 10^{10}$ & $-4,27 \times 10^{10}$ & $1,53 \times 10^{11}$ & $3,71 \times 10^{11}$ & $3,71 \times 10^{11}$ \\
& 6 & 597 & 2,04 & $1,052 \times 10^{12}$ & $1,60 \times 10^{20}$ & $1,60 \times 10^{21}$ & $3,19 \times 10^{21}$ & $3,19 \times 10^{21}$ \\
& 5 & 902 & 2,04 & $1,590 \times 10^{12}$ & $-1,41 \times 10^{12}$ & $1,73 \times 10^{11}$ & $1,94 \times 10^{12}$ & $1,94 \times 10^{12}$ \\
& 4 & 2.871 & 3,92 & $9,724 \times 10^{12}$ & $-9,55 \times 10^{12}$ & $-7,96 \times 10^{12}$ & $-6,20 \times 10^{12}$ & $-6,20 \times 10^{12}$ \\
& 4 & 2.355 & 7,86 & $1,599 \times 10^{13}$ & $-1,57 \times 10^{13}$ & $-1,26 \times 10^{13}$ & $-9,22 \times 10^{12}$ & $-9,22 \times 10^{12}$ \\
& 3 & 1.831 & 7,86 & $1,243 \times 10^{13}$ & $-1,18 \times 10^{13}$ & $-5,64 \times 10^{12}$ & $1,15 \times 10^{12}$ & $1,15 \times 10^{12}$ \\
\hline
\end{tabular}

Sumber: Analisis Penulis, 2018

Keterangan: DTBP: Daya Tampung Beban Pencemaran 
Pada segmen 3 tidak dapat menampung beban cemaran fecal coliform. Beban cemaran yang masuk ke sungai telah melewati batas beban cemaran yang diizinkan untuk setiap kelasnya. Tingginya jumlah fecal coliform pada segmen ini dikarenakan penduduk yang kurang peduli akan sanitasi dan juga banyaknya peternakan di sekitar DAS BKT. Tinja manusia dan peternakan menjadi penyebab utama tingginya jumlah fecal coliform. Daya tampung beban cemaran fecal coliform untuk kelas II sebesar -7,96 x 1.012 jumlah/hari. Tanda negatif menunjukkan bahwa Sungai BKT di segmen tidak memiliki daya tampung beban cemaran fecal coliform.

Pada segmen 4 tidak dapat menampung beban cemaran fecal coliform. Beban cemaran yang masuk ke sungai telah melewati batas beban cemaran yang diizinkan untuk setiap kelasnya. Beban cemaran fecal coliform tertinggi yang masuk ke sungai terdapat pada kilometer 3 yaitu sebesar 1,6 x 1.013 jumlah/hari. Tingginya beban cemaran fecal coliform tersebut merupakan yang tertinggi di sepanjang aliran DAS BKT. Hal ini dikarenakan segmen 4 merupakan daerah hilir yang terdapat banyak pemukiman, peternakan, dan industri. Daya tampung beban cemaran fecal coliform untuk kelas II yaitu sebesar -5,64 x $1.012 \mathrm{~kg} / \mathrm{hari}$. Nilai negatif menunjukkan bahwa sungai sudah tercemar dikarenakan tidak dapat menampung beban cemaran fecal coliform.

\section{Kesimpulan}

Kajian terkait DAS BKT sebagian besar membahas mengenai sistem hidrolika DAS BKT serta transportasi sungai untuk wisata dan kajian lingkungan pemanfaatan bantaran DAS BKT. Analisis terkait daya tampung di DAS BKT memanfaatan aplikasi numerik QUAL2E dapat digunakan untuk mengestimasi beban pencemaran serta status mutu air.

Upaya pengendalian pencemaran DAS BKT dapat dilakukan dengan membatasi beban pencemaran yang masuk ke DAS BKT. Berdasarkan hasil perhitungan yang telah dilakukan, beban pencemaran yang masuk ke dalam DAS BKT perlu dibatasi agar tidak mengakibatkan menurunnya kualitas air sungai. Beban pencemaran BOD dan fecal coliform yang masuk ke DAS BKT dibatasi agar tidak melebihi batas beban cemaran yang diizinkan.

Mengelola air limbah rumah tangga, air limbah rumah tangga perlu dikelola sebelum dialirkan secara langsung ke selokan atau sungai yaitu dengan cara membangun instalasi pembuangan air limbah (IPAL) komunal dan bagi daerah/lingkungan yang rata-rata penduduknya tidak memiliki water closet (WC) perlu disediakan WC umum yang dilengkapi dengan septic tank (Puspitasari, 2009). Pembangunan IPAL komunal dapat dilakukan dengan perencanaan yang mempertimbangkan luas daerah pemukiman dan jumlah penduduk.

Upaya pengendalian pencemaran perairan sungai juga dapat dilakukan dengan pencegahan kerusakan dan penurunan fungsi prasarana sungai seperti bendungan. Perlu juga dilakukan penanaman pohon kembali di daerah sempadan sungai untuk mengurangi beban pencemaran yang masuk ke sungai (Aftriana, 2013). Selain itu, perlu dilakukan normalisasi sungai yaitu membersihkan badan sungai dari sampah-sampah yang berada di sekitar badan sungai. Normalisasi dilakukan bertujuan untuk menambah kekasaran sungai ( $n$ manning) yang dilakukan dengan cara memasang batu-batuan dan memperdalam sungai sehingga kekasaran fisik sungai akan menjadi lebih besar.

\section{Ucapan Terima Kasih}

Penulis mengucapkan terima kasih kepada Direktorat Riset dan Pengabdian Masyarakat (DRPM) Kementerian Riset, Teknologi, dan Pendidikan Tinggi Melalui Penelitian Terapan Unggulan Perguruan Tinggi (PTUPT) Tahun Anggaran 2018 Kontrak 
No.101-151/UN7.P4.3/PP/2018 Tanggal 5 Februari 2018. Selain itu ucapan terima kasih juga ditujukan kepada Dinas Lingkungan Hidup Kota Semarang atas fasilitas laboratorium lingkungan.

\section{Daftar Pustaka}

Aftriana, C. V. (2013). Analisis perubahan kerapatan vegetasi Kota Semarang menggunakan aplikasi penginderaan jauh. Geo-Image, 2(2), 1-7. doi:10.15294/geoimage.v2i2.2188.

Anggani, H. (2005). Analisis lingkungan pemanfaatan Bantaran Sungai Banjir Kanal Timur (studi kasus di Kelurahan Kaligawe Semarang). Program Pascasarjana Universitas Diponegoro. Retrieved from http://eprints.undip.ac.id/11482/.

Anhwange, B. A., Agbaji, E. B., \& Gimba, E. . (2012). Impact assessment of human activities and seasonal variation on River Benue, within Makurdi Metropolis. International Journal of Science and Technology, 2(5), 248-254.

Asrori, M. N., \& Saputro, P. T. (2017). Analisis hidrologi Sungai Banjir Kanal Timur di Kawasan Sawah Besar Kelurahan Kaligawe Kota Semarang. Universitas Islam Sultan Agung. Retrieved from http://repository.unissula.ac.id/10348/.

Badan Pusat Statistik (BPS) Kota Semarang. (2016). Kota Semarang dalam angka 2016. Semarang: Badan Pusat Statistik Kota Semarang.

Badan Standarisasi Nasional (BSN). (2008). Standar Nasional Indonesia nomor 6898 bagian 57 tahun 2008 tentang metode pengambilan contoh air permukaan. Badan Standarisasi Nasional. Retrieved from http://sisni.bsn.go.id/.

Barnwell, Jr, T. O., Brown, L. C., \& Whittemore, R. C. (2004). Importance of field data in stream water quality modeling using QUAL2E-UNCAS. Journal of Environmental Engineering, 130(6). doi:10.1061/(asce)0733-9372(2004)130:6(643).

Blume, K., Macedo, J., Meneguzzi, A., Silva, L., Quevedo, D., \& Rodrigues, M. (2010). Water quality assessment of the Sinos River, Southern Brazil. Brazilian Journal of Biology, 7a4), 1185-1193. doi:10.1590/S151969842010000600008.

Brahmana, S. J., \& R, H. (2008). Pengendalian pencemaran sumber air dengan ekoteknologi (wetland buatan). Jurnal Sumber Daya Air, 4(2), 125-138.

Hakki, W., Sugiyanta, I. G., \& Haryono, E. (2015). Dampak pemanfaatan bantaran sungai terhadap kualitas lingkungan di Kelurahan Pasar Krui. Jurnal Penelitian Geografi, 3(4), 1-11.

Herlambang, A. (2006). Pencemaran air dan strategi penanggulangannya. Jurnal Air Indonesia, 2(1), 16-29. doi:10.29122/jai.v2i1.2280.

Jaworska, J. S., Masscheleyn, P., \& Mcavoy, D. C. (2001). Application of the QUAL2E water quality model for untreated discharge risk assessment in Central and Eastern Europe. In L. I \& P.-O. J (Eds.), Assessment and management of environmental risks (NATO Scien, pp. 163-172). Dordrecht, Netherlands: Springer. doi:10.1007/978-94-010-0987-4_16.

Kementerian Lingkungan Hidup Republik Indonesia. (2010). Peraturan Menteri Lingkungan Hidup Republik Indonesia nomor 1 tahun 2010 tentang tata laksana pengendalian pencemaran air. Kementerian Lingkungan Hidup Republik Indonesia. Retrieved from http://jdih.menlh.go.id/.

Keputusan Menteri Lingkungan Hidup Republik Indonesia. (2003a). Keputusan Menteri Lingkungan Hidup Republik Indonesia nomor 110 tahun 2003 tentang pedoman penetapan daya tampung beban pencemaran air pada sumber air. Jakarta. Retrieved from http://jdih.menlh.go.id/.

Keputusan Menteri Lingkungan Hidup Republik Indonesia. (2003b). Keputusan Menteri Lingkungan Hidup Republik Indonesia nomor 115 tahun 2003 tentang pedoman penentuan status mutu air. Jakarta. Retrieved from http://jdih.menlh.go.id/.

Kurniawan, T. V. (2017). Peran Badan Lingkungan Hidup dalam pengendalian pencemaran sungai Bengawan Solo di Kabupaten Sukoharjo. Jurnal Universitas Atma Jaya Yogyakarta. Yogyakarta: Universitas Atma Jaya. Retrieved from http://e-journal.uajy.ac.id/12254/.

Ma'rruf, A., Graha, A. S., Salamun, S., \& Ismiyati, I. (2015). Pengembangan Sungai Banjir Kanal Timur Semarang sebagai transportasi sungai untuk tujuan wisata. Jurnal Karya Teknik Sipil, 4(4), 107-120. 
Parveen, N., \& Singh, S. (2016). Application of Qual2e model for river water quality modelling. International Journal of Advance Research and Innovation, 4(2), 429-432.

Pavita, K. Della, Widiatmono, B. R., \& Dewi, L. (2014). Studi penentuan daya tampung beban pencemaran sungai akibat buangan limbah domestik (studi kasus Kali Surabaya-Kecamatan Wonokromo). Jurnal Sumberdaya Alam Dan Lingkungan, 1(3), 21-27. Retrieved from https://jsal.ub.ac.id/index.php/jsal/article/view/143.

Pemerintah Republik Indonesia. (2001). Peraturan Pemerintah Republik Indonesia nomor 82 tahun 2001 tentang pengelolaan kualitas air dan pengendalian pencemaran air. Retrieved from https://www.minerba.esdm.go.id.

Priyambada, I. B., Oktiawan, W., \& Suprapto, R. P. E. (2008). Analisa pengaruh perbedaan fungsi tata guna lahan terhadap beban pencemaran BOD sungai (studi kasus: Sungai Serayu Jawa Tengah). Jurnal Presipitasi: Media Komunikasi dan Pengembangan Teknik Lingkungan, 5(2), 55-62. doi:10.14710/presipitasi.v5i2.55-62.

Puspitasari, D. E. (2009). Dampak pencemaran air terhadap kesehatan lingkungan dalam perspektif hukum lingkungan (studi kasus Sungai Code Di Kelurahan Wirogunan Kecamatan Mergangsan dan Kelurahan Prawirodirjan Kecamatan Gondomanan Yogyakarta). Mimbar Hukum, 21(1), $24-34$. doi:10.22146/jmh.16254.

Rahayu, S., \& Tontowi, T. (2009). Penelitian kualitas air Bengawan Solo pada saat musim kemarau. Jurnal Sumber Daya Air, 5(2), 127-136.

Salmin, S. (2005). Oksigen terlarut (DO) dan kebutuhan oksigen biologi (BOD) sebagai salah satu indikator untuk menentukan kualitas perairan. Oseana, 30(3), 21-26.

Samudro, S., Agustiningsih, D., \& Sasongko, S. B. (2012). Analisis kualitas air dan strategi pengendalian pencemaran air Sungai Blukar Kabupaten Kendal. Jurnal Presipitasi: Media Komunikasi dan Pengembangan Teknik Lingkungan, 9(2), 64-71. doi:10.14710/presipitasi.v9i2.64-71.

Sholichin, M., Othman, F., \& Limantara, L. M. (2010). Use of PI and STORET methods to evalute water quality status of Brantas River. Journal of Mathematics and Technology, 3, 116-124.

Siahaan, R., Indrawan, A., Soedharma, D., \& Prasetyo, L. B. (2011). Kualitas air sungai Cisadane, Jawa BaratBanten. Jurnal Ilmiah Sains, 11(2), 268-273. doi:10.35799/jis.11.2.2011.218.

Sofia, Y., Tantowi, T., \& Rahayu, S. (2010). Penelitian pengolahan air sungai yang tercemar oleh bahan organik. Jurnal Sumber Daya Air, 6(2), 145-160.

Suparjo, M. N. (2009). Kondisi pencemaran perairan sungai Babon Semarang. Jurnal Saintek Perikanan, 4(2), 38-45. doi:10.14710/ijfst.4.2.38-45.

Sutriati, A. (2011). Penilaian kualitas air sungai dan potensi pemanfaatannya (studi kasus Sungai Cimanuk). Jurnal Sumber Daya Air, 71), 61-76.

Syofyan, I., Usman, U., \& Nasution, P. (2011). Studi kualitas air untuk kesehatan ikan dalam budidaya perikanan pada aliran Sungai Kampar Kiri. Jurnal Perikanan dan Kelautan, 16(1), 64-70. Retrieved from https://jpk.ejournal.unri.ac.id/index.php/JPK/article/view/48.

Vagnetti, R., Miana, P., Fabris, M., \& Pavoni, B. (2003). Self-purification ability of a resurgence stream. Chemosphere, 52(10), 1781-1795. doi:10.1016/S0045-6535(03)00445-4.

Winata, I. N. A., Siswoyo, A., \& Mulyono, T. (2000). Perbandingan kandungan P dan N total dalam air sungai di lingkungan perkebunan dan persawahan. Jurnal Ilmu Dasar, 1, 24-28.

Yudo, S. (2010). Kondisi kualitas air Sungai Ciliwung di wilayah DKI Jakarta ditinjau dari parameter organik, amoniak, fosfat, deterjen dan bakteri coli. Jurnal Air Indonesia, 6(1), 34-42.

Yuwono, E., \& Setyobudiarso, H. (2016). Sinkronisasi status mutu dan daya tampung beban pencemaran air Sungai Metro. In Seminar Nasional Inovasi dan Aplikasi Teknologi di Industri (SENIATI) 2016 (pp. 4154). Malang: Institut Teknologi Nasional Malang. 